PACS: $29.17 .+\mathrm{w} ;$ 41.75.Lx;

\title{
UNIFORM FOCUSING OF SEQUENCE OF RELATIVISTIC POSITRON BUNCHES IN PLASMA
}

\author{
(D) Vasyl Maslov ${ }^{1,2 *}$, Denys Bondar ${ }^{2}$, (Dryna Levchuk ${ }^{1}$, (Dofiia Nikonova ${ }^{2}$, \\ (iD) Ivan Onishchenko ${ }^{1}$ \\ ${ }^{1}$ NSC "Kharkiv Institute of Physics and Technology" NASU \\ Kharkiv, 61108, st. Akademicheskaya 1, Ukraine \\ ${ }^{2}$ V.N. Karazin Kharkiv National University \\ 4 Svobody Sq., Kharkiv, 61022, Ukraine \\ *E-mail:vmaslov@kipt.kharkov.ua \\ Received April 8, 2019; revised April 23, 2019; accepted May 31, 2019
}

Plasma-based accelerators sustain accelerating gradients which are several orders greater than obtained in conventional accelerators. Focusing of electron and positron beams by wakefield, excited in plasma, in electron-positron collider is very important. The focusing mechanism in the plasma, in which all electron bunches of a sequence are focused identically, has been proposed by authors earlier. The mechanism of focusing of a sequence of relativistic positron bunches in plasma, in which all positron bunches of sequence are focused identically and uniformly, has been investigated in this paper by numerical simulation by 2.5D code LCODE. Mechanism of this identical and uniform focusing involves the use of wave-length $\lambda$, which coinciding with double longitudinal dimension of bunches $\lambda=2 \Delta \mathrm{b}$, the first bunch current is in two times smaller than the current of the following bunches of sequence and the distance between bunches equals to one and a half of wavelength $1.5 \lambda$. We numerically simulate the self-consistent radial dynamics of lengthy positron bunches in homogeneous plasma. In simulation we use the hydrodynamic description of plasma. In other words the plasma is considered to be cold electron liquid, and positron bunches are aggregate of macroparticles. Positron bunches are considered to be homogeneous cylinders in the longitudinal direction. Positrons in bunches are distributed in radial direction according to Gaussian distribution. It is shown that in this case only first bunch is in the finite longitudinal electrical wakefield $E_{z} \neq 0$. Other bunches are in zero longitudinal electrical wakefield $E_{z}=0$. Between bunches of this sequence longitudinal electrical wakefield and radial force are not zero $\mathrm{E}_{z} \neq 0, \mathrm{~F}_{\mathrm{r}} \neq 0$. The focusing radial force in regions, occupied by bunches, is constant along each bunch $\mathrm{F}_{\mathrm{r}}=$ const. Between bunches the radial force is inhomogeneous $\mathrm{F}_{\mathrm{r}} \neq$ const. All positron bunches of sequence are focused identically and uniformly.

KEYWORDS: electron bunch focusing, positron bunch focusing, plasma wakefield lens, particle acceleration, numerical simulation.

Plasma-based accelerators sustain accelerating gradients which are several orders greater than obtained in conventional accelerators [1-3]. Accelerating wakefield can be excited by single electron bunch [4,5]. As plasma is inhomogeneous and nonstationary it is difficult to excite wakefield resonantly by a long sequence of electron bunches $[6,7]$, to focus sequence [8-12], to prepare sequence from long beam [13-15] and to provide large transformer ratio [16-22]. In [7] the mechanism has been found and in [23-26] investigated of resonant plasma wakefield excitation by a nonresonant sequence of short electron bunches.

Focusing of electron and positron beams by wakefield, excited in plasma, in electron-positron collider is very important $[8-10,27-30]$. The focusing mechanism in the plasma, in which all electron bunches of a sequence are focused identically, has been proposed in [8-10]. However, investigations show that in a strongly nonlinear regime the value and spatial distribution of wakefield, excited by sequence of positron bunches, are different in comparison with the value and spatial distribution of wakefield, excited by sequence of electron bunches. Therefore this lens for relativistic positron bunches is researched in this paper by numerical simulation by $2.5 \mathrm{D}$ code LCODE [31]. Code LCODE treats plasma as a cold electron fluid and the bunches as ensembles of macro-particles. Electron beam is represented by a sequence of 4 and 10 electron bunches.

The article deals only with the focusing process. This regime can take place in the following cases:

-before the meeting point of colliding beams;

- during beam transport;

-in conditions with spatially separated processes of acceleration and focusing.

We use the cylindrical coordinate system $(r, z)$ and plot wakefields, plasma and beam densities at some $z$ as functions of the dimensionless value $\xi=\left(\mathrm{z}-\mathrm{V}_{\mathrm{b}} \mathrm{t}\right), \mathrm{V}_{\mathrm{b}}$ is the velocity of bunches.

Wakefield is normalized on $\mathrm{E}_{0}=\mathrm{cm} \omega_{\mathrm{p}} / \mathrm{e}$, where $\mathrm{m}$ is the electron mass, $\mathrm{e}$ is the elementary charge, $\mathrm{c}$ is the speed of light, and $\omega_{\mathrm{p}}=\left(4 \pi \mathrm{n}_{0} \mathrm{e}^{2} / \mathrm{m}\right)^{1 / 2}$ is the plasma frequency. Time $\mathrm{t}$ is normalized on $\omega_{\mathrm{pe}}{ }^{-1}$, longitudinal momentum of bunches $\mathrm{P}_{\mathrm{z}}$ - on $\mathrm{mc} \gamma_{\mathrm{b}}$, radius of bunches on $\mathrm{c} / \omega_{\mathrm{p}}$, beam current $\mathrm{I}_{\mathrm{b}}-\mathrm{on} \mathrm{mc}^{3} / \mathrm{e}$, emittance of bunches $\sigma-\mathrm{on}^{2} / \omega_{\mathrm{p}}$; plasma electron density $n_{e}$ and bunch density $n_{b}$ are normalized on unperturbed plasma electron density $n_{0}$, radial $r$ and longitudinal $z$ coordinates - on $\mathrm{c} / \omega_{\mathrm{p}}$.

All bunches of sequence are focused identically and uniformly. By code LCODE we simulate the behavior of positron bunches of finite dimension in uniform plasma. The code simulate plasma electrons, using the hydrodynamic 
equations. In other words the plasma electrons are considered to be cold electron liquid, and bunches are aggregate of macroparticles.

Aim of paper is to show that all relativistic positron bunches of sequence can be focused identically and uniformly and to derive conditions for achievement of identical and uniform focusing of relativistic positron bunches of sequence.

\section{RESULTS OF SIMULATION}

Let us study focusing of positron bunches of sequence by wave, which wave-length coinciding with double longitudinal dimension of bunches. This case is interesting, since at growth of bunch longitudinal dimension at fixed its current the amplitude of wakefield reaches highest value at $\lambda=2 \Delta_{\mathrm{b}}$. We apply the first bunch current is in two times smaller than the current of the following bunches of sequence $\mathrm{I}_{1}=\mathrm{I} / 2, \mathrm{I}_{\mathrm{i}}=\mathrm{I}, \mathrm{i}=2,3,4 \ldots$, spatial dimension from one bunch to another coincides with $1.5 \lambda, \lambda$ is used wave-length of wakefield. In this case the distribution of excited longitudinal wakefield $E_{z}$, radial wake force $F_{r}$ and magnetic field $H_{\theta}$ are of the form, shown in Fig. 1 for four bunches.

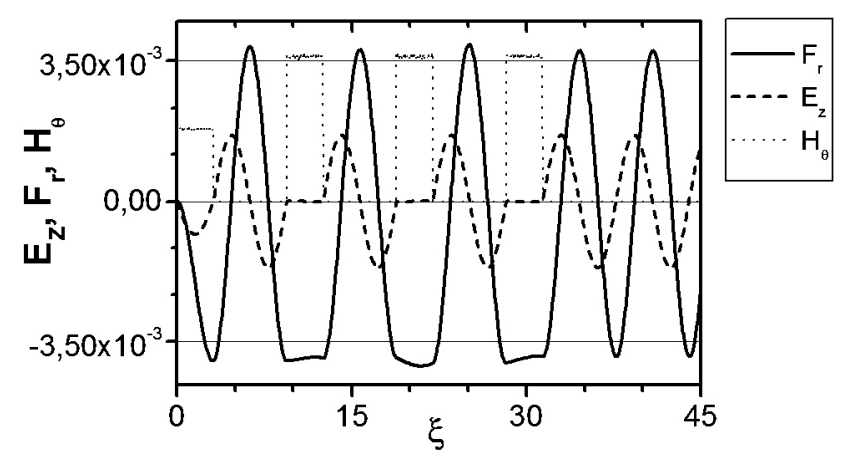

Fig. 1. Off-axis longitudinal wakefield $\mathrm{E}_{\mathrm{z}}(---)$, off-axis radial wake force $\mathrm{F}_{\mathrm{r}}(----)=\mathrm{E}_{\mathrm{r}}-\mathrm{V}_{\mathrm{b}} \mathrm{H}_{\theta} / \mathrm{c}$ and off-axis magnetic field $\mathrm{H}_{\theta}(\cdots \cdots \cdot)$ for $\mathrm{z}=3, \gamma_{\mathrm{b}}=5, \mathrm{I}_{\mathrm{b}}=0.3 \times 10^{-3}, \mathrm{r}_{\mathrm{b}}=0.1, \gamma_{\mathrm{b}}$ is the relativistic factor of bunches, $\mathrm{Ib}_{\mathrm{b}}$ is the maximal beam current. $\mathrm{E}_{\mathrm{z}}, \mathrm{F}_{\mathrm{r}}, \mathrm{H}_{\theta}$ have been calculated for radius $r=r_{b}$

In Fig. 1 one can see positions of bunches by positions $\mathrm{H}_{\theta}$, because magnetic field is created by beam current. From Fig. 1 it is evidently, that first bunch is in $E_{z} \neq 0$ and it excites wakefield. All following bunches are in $E_{z}=0$ and they do not excite wakefield. Hence wakefield does not change from one bunch to another. However the sequence is focused since amplitude of transversal wake force is finite $\mathrm{F}_{\mathrm{r}} \neq 0$ in areas of bunches.

It is necessary to list the distinctive characteristics of the lens of this mechanism:

1) radial wake force $F_{r}$ does not approximately depend on coordinate in regions, occupied by bunches (with the exception of first bunch), $\mathrm{F}_{\mathrm{r}} \approx$ const, i.e. lengthy bunches are focused identically;

2) only first bunch is decelerated;

3) identical focusing force effects on all bunches (with the exception of first bunch);

4) longitudinal wakefield equal zero $E_{z}=0$ in regions, occupied by bunches (with the exception of first bunch).

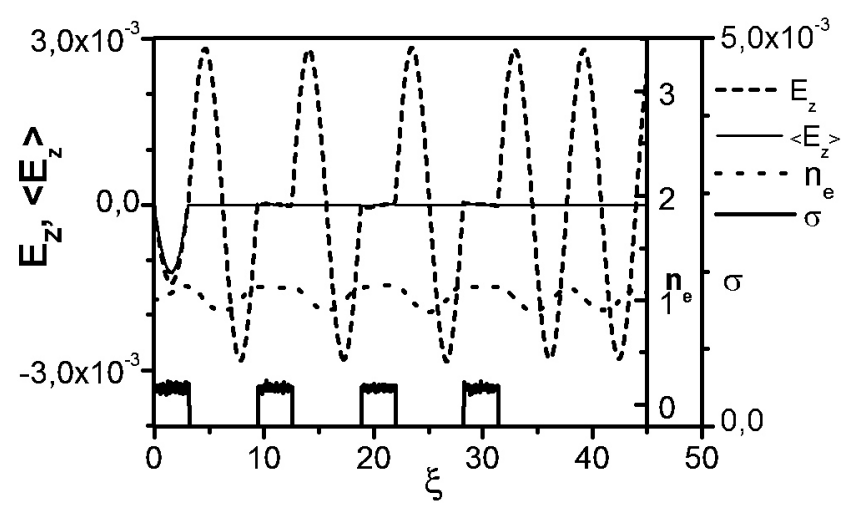

Fig. 2. On-axis plasma electron density $n_{e}(\cdots \cdots \cdots)$ in wakefield, emittance of bunches $\sigma$ (------), on-axis longitudinal wakefield $E_{z}(--$ -) and $\left\langle\mathbf{E}_{\mathbf{z}}>=\int \mathrm{dr} r \mathrm{E}_{\mathrm{z}} \mathrm{n}_{\mathrm{b}} / \int \mathrm{dr} \mathrm{rn}_{\mathrm{b}}(------)\right.$ coupling rate of bunch with wakefield $\mathrm{E}_{\mathrm{z}}$ for $\mathrm{z}=3, \gamma_{\mathrm{b}}=5, \mathrm{I}_{\mathrm{b}}=0.3 \times 10^{-3}, \mathrm{r}_{\mathrm{b}}=0.1$

Such ideal focusing (Fig. 3) is realized due to formation of flat elevations of plasma electron density $\mathrm{n}_{\mathrm{e}}$ in areas of bunches (Fig. 2). These flat elevations compensate charges of bunches but magnetic field of current of bunches focuses them. In first bunch area (Fig. 2), the excited elevation of plasma electron density $n_{e}$ is not uniform. As a result first 
bunch nonuniform focusing is developed (Fig. 3). It is evidently from Fig. 2 that perturbation of density of plasma electrons $n_{e}$ is periodic but non-sinusoidal: long elevations of $n_{e}$ (as opposed to area of first bunch) are alternated by short decreases of $\mathrm{n}_{\mathrm{e}}$. The bunches are located in the regions of the elevations of $\mathrm{n}_{\mathrm{e}}$.
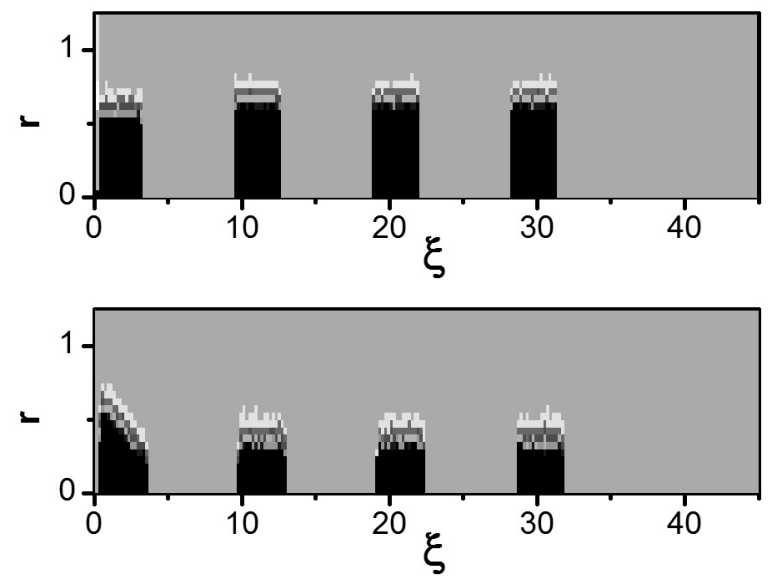

Fig. 3. The spatial $(\mathrm{r}, \xi)$ distribution of electron density $\mathrm{n}_{\mathrm{b}}$ of bunches before focusing (near the boundary of beam injection, $\mathrm{z}=3$ ) and after focusing (into the plasma on the distance $\mathrm{z}=20$ from the boundary of beam injection) for $\gamma_{\mathrm{b}}=5, \mathrm{I}_{\mathrm{b}}=0.3 \times 10^{-3}, \mathrm{r}_{\mathrm{b}}=0.1$.

Black corresponds to the maximum density, and gray- to zero

In linear approximation relation $\mathrm{E}_{\mathrm{r}} \sim \partial_{\mathrm{r}} \mathrm{E}_{\mathrm{z}}$ for transversal and longitudinal wakefields is known. But in our case it is erroneous (One can see Fig. 1). It is obviously from Figs. 1-2 that positive and negative perturbations of $E_{z}$ are alternated, compensating each other. The latter leads to observed fact that along the final areas of dimension $\lambda / 2$ of positions of bunches the longitudinal wakefield $E_{z}$ is compensated. But in these areas of positions of bunches the transversal force $\mathrm{F}_{\mathrm{r}}$ is finite $\mathrm{F}_{\mathrm{r}} \neq 0$.

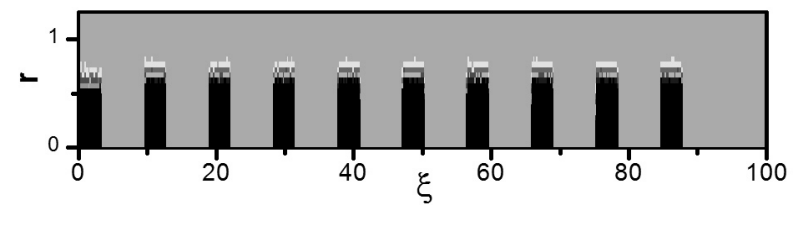

Fig. 4. The spatial distribution of electron density $n_{b}$ of ten bunches before focusing for $z=3, \gamma_{b}=1000, I_{b}=0.3 \times 10^{-3}, r_{b}=0.1$. Black corresponds to the maximum density, and gray - to zero

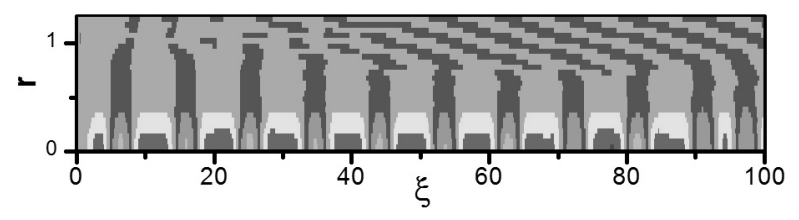

Fig. 5. Plasma electron density $n_{e}$ in wakefield, excited by ten bunches for $z=3, \gamma_{b}=1000, I_{b}=0.3 \times 10^{-3}, r_{b}=0.1$

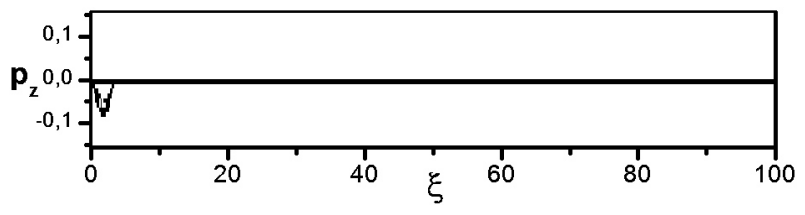

Fig. 6. Change of longitudinal momentum of bunches $\mathrm{P}_{\mathrm{z}}$ at wakefield excitation for $\mathrm{z}=80, \gamma_{\mathrm{b}}=1000, \mathrm{I}_{\mathrm{b}}=0.3 \times 10^{-3}, \mathrm{r}_{\mathrm{b}}=0.1, \mathrm{p}_{\mathrm{z}}=\mathrm{P}_{\mathrm{z}}-1$

Let us show that similar behavior and dependencies are observed for another number of bunches. In particular, we simulate the case of ten bunches (one can see Fig. 4). Similar to the case of four bunches, the first bunch current is in two times smaller than the current of the following bunches of sequence $\mathrm{I}_{1}=\mathrm{I} / 2, \mathrm{I}_{\mathrm{i}}=\mathrm{I}, \mathrm{i}=2,3,4 \ldots$, spatial dimension from one bunch to another coincides with $1.5 \lambda$. One can see the plasma electron density $n_{e}$ perturbation, excited longitudinal wakefield $\mathrm{E}_{\mathrm{z}}$, radial wake force $\mathrm{F}_{\mathrm{r}}$, magnetic field $\mathrm{H}_{\theta}$, average wakefield $<\mathrm{E}_{\mathrm{z}}>$, momentum of bunches $\mathrm{P}_{\mathrm{z}}$ in Figs. 4-8. One can see that behavior and dependencies are identical to the case of four bunches. Namely, Fig. 7 
demonstrates that in the case of ten bunches also $\left\langle\mathrm{E}_{\mathrm{Z}}>\right.$ for only bunch on front of sequence is finite and hence only bunch on front of sequence is decelerated (Fig. 6).

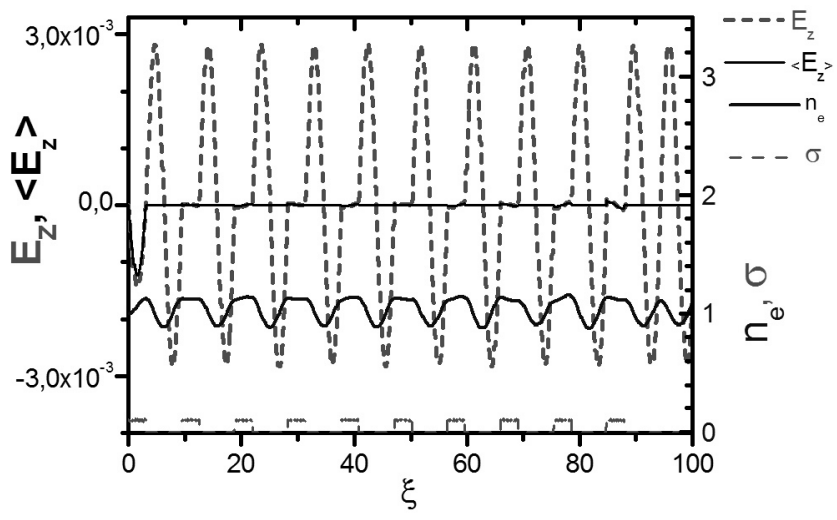

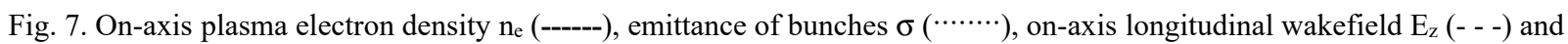
$<\mathbf{E}_{\mathbf{z}}>$ (-----) coupling rate of bunch with wakefield $\mathrm{E}_{\mathrm{z}}$ for $\mathrm{z}=3, \gamma_{\mathrm{b}}=1000, \mathrm{I}_{\mathrm{b}}=0.3 \times 10^{-3}, \mathrm{r}_{\mathrm{b}}=0.1$

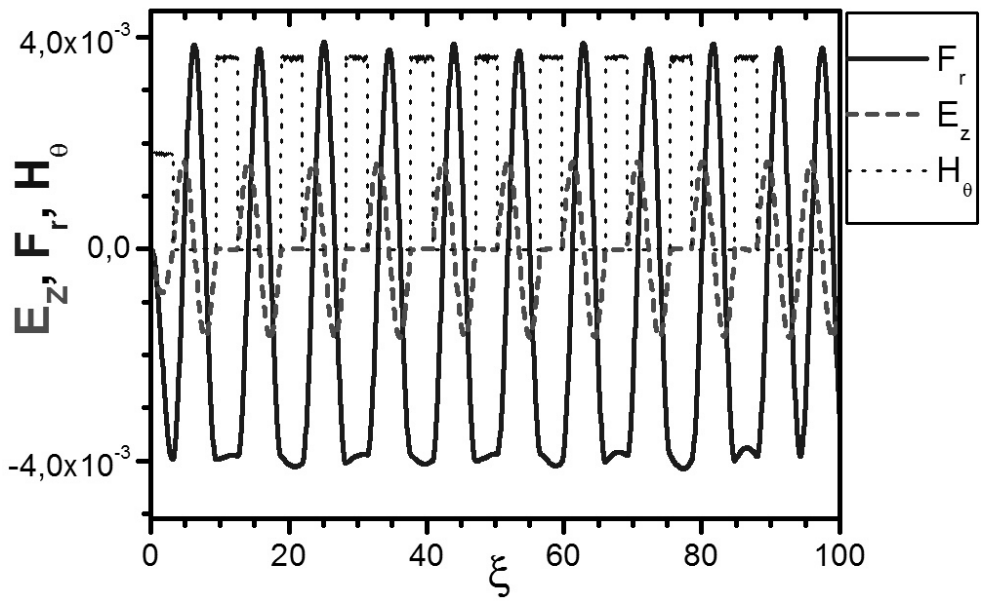

Fig. 8. Off-axis longitudinal wakefield $\mathrm{E}_{\mathrm{z}}(---)$, off-axis radial wake force $\mathrm{F}_{\mathrm{r}}(----)$ and off-axis magnetic field $\mathrm{H}_{\theta}(\cdots \cdots)$ for $\mathrm{z}=3$, $\gamma_{b}=1000, I_{b}=0.3 \times 10^{-3}, r_{b}=0.1 . E_{z}, F_{r}, H_{\theta}$ have been calculated for radius $r=r_{b}$

Again one can see (Fig. 8) that only 1-st bunch is in finite $\mathrm{E}_{z} \neq 0$. Other bunches are in zero longitudinal electrical wakefield $\mathrm{E}_{\mathrm{z}}=0$. Radial wake force $\mathrm{F}_{\mathrm{r}}$ in regions, occupied by bunches, is finite (Fig. 8).

\section{CONCLUSION}

It has been shown that in considered conditions all relativistic positron bunches unlike a bunch at the front of sequence are focused equally and homogeneously (Fig. 3) similar to electron bunches. For this it is necessary that wave-length coinciding with double longitudinal dimension of bunches, the first bunch current is in two times smaller than the current of the following bunches of sequence, spatial dimension from one bunch to another coincides with 1.5 $\lambda$. From results of simulations one can conclude that only bunch on the front of sequence interacts with wakefield. All next bunches are in areas, where longitudinal wakefield equals zero. Therefor only bunch on the front of sequence excites wakefield. The next bunches do not excite wakefield. Hence value of wakefield does not increase along sequence. Transversal force in areas of bunches is the same and homogeneous along bunches.

\section{ORCID IDs}

Vasyl Maslov@https://orcid.org/0000-0002-4370-7685, Denys Bondar@https://orcid.org/0000-0002-7358-4305, Iryna Levchuk@https://orcid.org/0000-0003-0542-0410, Sofiia Nikonova $@$ https://orcid.org/0000-0003-3201-6077, Ivan Onishchenko (i)http://orcid.org/0000-0002-8025-5825

\section{REFERENCES}

[1]. E. Esarey, C.B. Schroeder and W.P. Leemans, Rev. Mod. Phys., 81, 1229-1285 (2009), doi: 10.1103/RevModPhys.81.1229.

[2]. A. Pukhov and J. Meyer-ter-Vehn, Apl. Phys. B., 74, 355-361 (2002), doi: 10.1007/s003400200795.

[3]. K.V. Lotov, V.I. Maslov, I.N. Onishchenko and E.N. Svistun, Problems of Atomic Science and Technology, 6, 114-116 (2008).

[4]. K.V. Lotov, V.I. Maslov, I.N. Onishchenko and E.N. Svistun, Plasma Phys. Cont. Fus., 52, 065009 (2010), doi: 10.1088/07413335/52/6/065009. 
[5]. K.V. Lotov, V.I. Maslov, I.N. Onishchenko and E.N. Svistun, Problems of Atomic Science and Technology. 3, 159-163 (2012).

[6]. V.I. Maslov, I.N. Onishchenko and I.P. Yarovaya, Problems of Atomic Science and Technology. 1, 134-136 (2013).

[7]. V.I. Maslov, I.N. Onishchenko and I.P. Yarovaya, East European Journal of Physics. 1(2), 92-95 (2014).

[8]. I.P. Levchuk, V.I. Maslov and I.N. Onishchenko, Problems of Atomic Science and Technology. 4, 120-123 (2015).

[9]. I.P. Levchuk, V.I. Maslov and I.N. Onishchenko, Problems of Atomic Science and Technology. 3, 62-65 (2016).

[10]. K.V. Lotov, V.I. Maslov, I.N. Onishchenko and M.S. Vesnovskaya, Problems of Atomic Science and Technology. 4, 12-16 (2010).

[11]. K.V. Lotov, V.I. Maslov, I.N. Onishchenko and M.S. Vesnovskaya, Problems of Atomic Science and Technology. 1, 83-85 (2011).

[12]. V.A. Balakirev, I.N. Onishchenko and V.I. Maslov, Problems of Atomic Science and Technology. 3, 92-95. (2011).

[13]. K.V. Lotov, V.I. Maslov and I.N. Onishchenko, Problems of Atomic Science and Technology. 4, 85-89. (2010).

[14]. K.V. Lotov, V.I. Maslov, I.N. Onishchenko and I.P. Yarovaya, Problems of Atomic Science and Technology. 3, 87-91 (2011).

[15]. V.I. Maslov, I.N. Onishchenko and I.P. Yarovaya, Problems of Atomic Science and Technology. 4, 128-130 (2012).

[16]. V.I. Maslov, I.N. Onishchenko and I.P. Yarovaya, Problems of Atomic Science and Technology. 6, 161-163 (2012).

[17]. I.P. Levchuk, V.I. Maslov and I.N. Onishchenko, Problems of Atomic Science and Technology. 6, 37-41. (2015).

[18]. I.P. Levchuk, V.I. Maslov and I.N. Onishchenko, Problems of Atomic Science and Technology. 6, 43-46. (2017).

[19]. D.S. Bondar, I.P. Levchuk, V.I. Maslov, I.N. Onishchenko, East Eur. J. Phys. 5(2), 72-77. (2018).

[20]. K.V. Lotov, V.I. Maslov, I.N. Onishchenko and E.N. Svistun, Problems of Atomic Science and Technology. 2, 122-124 (2010).

[21]. V. Lotov, V.I. Maslov, I.N. Onishchenko, E.N. Svistun and M.S. Vesnovskaya, Problems of Atomic Science and Technology. 6, 114-116 (2010).

[22]. K.V. Lotov, V.I. Maslov and I.N. Onishchenko, Problems of Atomic Science and Technology. 6, 103-107 (2010).

[23]. K.V. Lotov, V.I. Maslov, I.N. Onishchenko and I.P.Yarovaya, Problems of Atomic Science and Technology. 4, 73-76 (2013).

[24]. G. Hairapetian, P. Devis, C. Joshi, C. Pelegrin and T. Katsouleas, Phys. Plasma. 2(2555) 1995, doi: 10.1063/1.871217.

[25]. Ya.B. Fainberg, N.I. Ayzatsky, V.A. Balakirev, A.K. Berezin, A.N. Dovbnya, V.I. Karas', V.A. Kiselev, V.A. Kushnir, A.F. Linnik, V.V. Mitrochenko, V.D. Stepin, I.N. Onishchenko, A.P. Tolstoluzhsky and V.V. Uskov, in: Proceedings PAC'97, Edited by M. Comyn, M.K. Craddock, M. Reiser, J. Thomson (IEEE, Vancouver, 1997). 2, pp. 651-653, doi: 10.1109/PAC.1997.749794.

[26]. J.-H. Röckemann, L. Schaper, S. K. Barber, N. A. Bobrova, G. Boyle, S. Bulanov, N. Delbos, K. Floettmann, G. Kube, W. Lauth, W. P. Leemans, V. Libov, A. R. Maier, M. Meisel, P. Messner, P. V. Sasorov, C. B. Schroeder, J. van Tilborg, S. Wesch, and J. Osterhoff, Phys. Rev. Accel. \& Beams. 21, 122801 (2018), doi: 10.1103/PhysRevAccelBeams.21.122801.

[27]. C. O’Connell, F-J. Decker, M.J. Hogan, R. Iverson, P. Raimondi, R.H. Siemann, D. Walz, B. Blue, C.E. Clayton, C. Joshi, K.A. Marsh, W.B. Mori, S. Wang, T. Katsouleas, S. Lee, and P. Muggli, Phys. Rev. Accel. \& Beams. 5, 121301 (2002), doi: 10.1103/PhysRevSTAB.5.121301.

[28]. M.C. Thompson, H. Badakov, J.B. Rosenzweig, G. Travish, R. Fliller, G.M. Kazakevich, P. Piot, J. Santucci, J. Li, and R. Tikhoplav, AIP Conference Proceedings, 877, 561 (2006), doi: 10.1063/1.2409184.

[29]. S.Yu. Kalmykov, L.M. Gorbunov, P. Mora and G. Shvets, Phys. Plasmas. 13,113102. (2006), doi: 10.1063/1.2363172.

[30]. G.V. Sotnikov, R.R. Kniaziev, O.V. Manuilenko, P.I. Markov, T.C. Marshall and I.N. Onishchenko, Nuclear Instruments and Methods in Physics Research A. 740, 124-129 (2014), doi: 10.1016/j.nima.2013.10.087.

[31]. K.V. Lotov, Phys. Plasmas. 5(3), 785-791 (1998), doi: 10.1063/1.872765.

\section{ОДНОРІДНЕ ФОКУСУВАННЯ ПОСЛІДОВНОСТІ РЕЛЯТИВІСТСЬКИХ ПОЗИТРОННИХ ЗГУСТКІВ У ПЛАЗМІ В.І. Маслов, Д.С. Бондарь, І.П. Левчук, С.А. Ніконова, І.М. Онищенко \\ ${ }^{1}$ Національний Науковий Центр «Харківський фізико-технічний інститут» 61108, Харків,вул. Академічна, 1 \\ ${ }^{2}$ Харківський національний університет імені В.Н. Каразіна \\ пл. Свободи 4, Харків, 61022, Украӥна}

Плазмові прискорювачі забезпечують прискорюючи поля, які на кілька порядків більше, ніж у звичайних прискорювачах. В електрон-позитронних коллайдерах дуже важливе фокусування електронних i позитронних пучків за допомогою кільватерного поля, збудженого в плазмі. Механізм фокусування в плазмі, при якому всі електронні згустки послідовності фокусуються однаково, був запропонований авторами раніше. Механізм фокусування послідовності релятивістських позитронних згустків в плазмі, при якому всі позитронні згустки послідовності фокусуються однаково і однорідне, досліджується в даній роботі шляхом числового моделювання з використанням 2.5D коду LCODE. У цій схемі фокусування необхідно, щоб довжина кожного згустку дорівнювала половині довжини хвилі $\xi_{\mathrm{b}}=\lambda / 2$, заряд першого згустку дорівнює

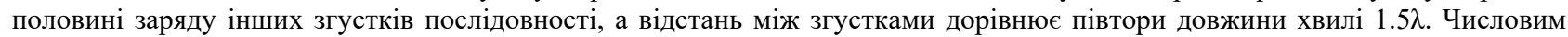
моделюванням досліджується самоузгоджена радіальна динаміка довгих згустків позитронів в однорідній плазмі. При моделюванні ми використовуємо гідродинамічний опис плазми. Іншими словами, плазма вважається холодною електронною рідиною, а позитронні згустки являють собою сукупність макрочастинок. Згустки позитронів розглядаються однорідними в поздовжньому напрямку циліндрами. Позитрони в згустках розподіляються в радіальному напрямку згідно гауссівському розподілу. Показано, що в цьому випадку тільки перший згусток знаходиться в кінцевому поздовжньому електричному полі $E_{z} \neq 0$. Решта згустків знаходиться в нульовому поздовжньому електричному кільватерному полі $\mathrm{E}_{z}=0$. Між згустками цієї послідовності поздовжнє електричне кільватерних поле і радіальна сила не дорівнюють нулю $\mathrm{E}_{z} \neq 0, \mathrm{~F}_{\mathrm{r}} \neq 0$. Фокусуюча радіальна сила в областях, зайнятих згустками, $є$ постійною уздовж кожного згустку $\mathrm{F}_{\mathrm{r}} \neq \mathrm{const}$. Мiж згустками радіальна сила неоднорідна. Всі позитронні згустки послідовності фокусуються однаково і однорідно.

КЛЮЧОВІ СЛОВА: фокусування згустків електронів, фокусування згустків позитронів, плазмова кільватерна лінза, прискорення частинок, чисельне моделювання. 
ОДНОРОДНАЯ ФОКУСИРОВКА ЦЕПОЧКИ РЕЛЯТИВИСТСКИХ ПОЗИТРОННЫХ СГУСТКОВ В ПЛАЗМЕ

В.И. Маслов, Д.С. Бондарь, И.П. Левчук, С.А. Никонова, И.Н. Онищенко

${ }^{I}$ Национальный Научный Центр «Харьковский физико-технический институт» 61108, Харьков, ул. Академическая, 1

${ }^{2}$ Харьковский национальный университет имени В.Н. Каразина пл. Свободьи 4, Харьков, 61022, Украина

Плазменные ускорители обеспечивают ускоряющие поля, которые на несколько порядков больше, чем у обычных ускорителей. В электрон-позитронных коллайдерах очень важна фокусировка электронных и позитронных пучков с помощью кильватерного поля, возбужденного в плазме. Механизм фокусировки в плазме, при котором все электронные сгустки последовательности фокусируются одинаково, был предложен авторами ранее. Механизм фокусировки последовательности релятивистских позитронных сгустков в плазме, при котором все позитронные сгустки последовательности фокусируются одинаково и однородно, исследуется в данной работе путем численного моделирования с использованием 2.5D кода LCODE. В этой схеме фокусировки необходимо, чтобы длина каждого сгустка была равна половине длины волны $\xi_{\mathrm{b}}=\lambda / 2$, заряд первого сгустка равен половине заряда остальных сгустков последовательности, а расстояние между сгустками равно полутора длины волны $1.5 \lambda$. Численным моделированием исследуется самосогласованная радиальная динамика длинных сгустков позитронов в однородной плазме. При моделировании мы используем гидродинамическое описание плазмы. Другими словами, плазма считается холодной электронной жидкостью, а позитронные сгустки представляют собой совокупность макрочастиц. Сгустки позитронов рассматриваются однородными в продольном направлении цилиндрами. Позитроны в сгустках распределяются в радиальном направлении согласно гауссовскому распределению. Показано, что в этом случае только первый сгусток находится в конечном продольном электрическом поле $\mathrm{E}_{\mathrm{z}} \neq 0$. Остальные сгустки находятся в нулевом продольном электрическом кильватерном поле $\mathrm{E}_{\mathrm{z}}=0$. Между сгустками этой последовательности продольное электрическое кильватерное поле и радиальная сила не равны нулю $\mathrm{E}_{z} \neq 0, \mathrm{~F}_{\mathrm{r}} \neq 0$. Фокусирующая радиальная сила в областях, занятых сгустками, является постоянной вдоль каждого сгустка $\mathrm{F}_{\mathrm{r}} \neq$ const. Между сгустками радиальная сила неоднородна. Все позитронные сгустки последовательности фокусируются одинаково и однородно.

КЛЮЧЕВЫЕ СЛОВА: фокусировка сгустков электронов, фокусировка сгустков позитронов, плазменная кильватерная линза, ускорение частиц, численное моделирование. 